\title{
A CASE OF MULTIPLE SCLEROSIS AND ITS NEURO-OTOLOGICAL EVALUATIONS
}

\author{
OSAMU TOKUNAGA, M.D., SUSUMU WATANABE, M.D.,
}

AND TOMOKO YANAGITA, M.D.

Department of Otorhinolaryngology, Faculty of Medicine, Kyushu University, Fukuoka.

(Director: I. Hiroto, M.D.)

Multiple sclerosis is rarely reported in Japan. The incidence of the disease in Japan is said to be about $2 \%$ of that in Europe and North America. The disease, therefore, has not been so much evaluated neuro-otologically in Japan. The patient was 22-year-old female, complaining of vertigo, hearing disturbance of the left ear and hypesthesia of the upper and the lower extremities. The examinations revealed slight left ear hearing loss in pure tone audiometry, marked positive TTS in Békésy audiometry of the left ear, horizontal gaze nystagmus to the bilateral directions, direction fixed positional nystagmus to the left, and DP to the left in caloric test. Optokinetic nystagmus and eye-tracking tests were normal. These neuro-otological findings gradually disappeared in about 5 months except hypesthesia of the lower extremity which remains at present.

A80-0489-25501

\section{多発性硬化症と聴覚平衡障害}

一自験疑症例と文献的考察—

\section{九州大学医学部耳鼻咽喉科学教室(主任: 広戸幾一郎教授)}

徳永修・渡辺晋・楖田と旡子

$$
\text { はじめに }
$$

本症例似は発病当初, 回転性メマイや奞㯖などの内且 障害偟よる疾患を思わせる症状があり，メ二エール病と

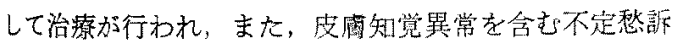
のことき症状の消長を伴ったためか，心身症として対処

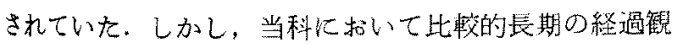

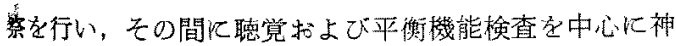
释学的検查を行った結果から, 多発性硬化症 multiple sclerosis を強く疑ったもので市る. 神経耳科学的異常 所見が消失（緩解）するに至ったので，自駼例の臨本所 見梠よび椧查成禎を述へ，文献的考察を屯併せて報告す る.

\section{患者: 中村 00 女 22 歲 ウエートレス}

当科初款: 1973年4月19日

主訴：回転性メマイ，左難聴捄よび四肢知覚異常
既往歴・家接歴：特記事項なし

\section{自覚症の経過}

1969年頃：顔面右半側の知觉鈍标に氛付いたか，䄪 1 週間で自然に消失した，その後，左半側の知筧罢常も一 時的飞認めている。

1972年7月21日：初回のメアイあり。起床直後化回転

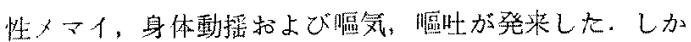
し、耷鳴や難誜は自覚しなかった。某院に入院し、メ二 エール病として約 3 週間の治療を受け上記症状は改善し た.

1972年11月12日：左下腿（特心灾くらはぎ）と右崩驺

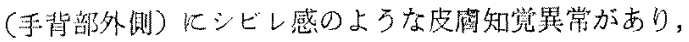
步行時つかまり歩き，階段を降り難いなとの症状が起一 た，九大神経内科を受彮したが，両滕より末梢側に㹩度

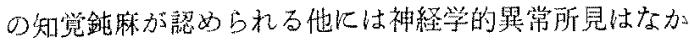
った，その頃から，再び歩行時心らつきの增鱼とメマイ 
感も扣わったため，九大心療内科党受彰の上，心身症の 疑いとして某院に入院した、VB郕，血管搪㖘剂，精神 安定剤などの内服を続け，潮次自喾症は改善されて行っ た。

1973年3月25日：再び起床直後汇激しい回転性メマ1

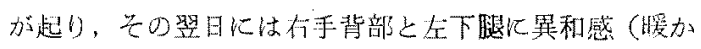
い感じ) や，滕がガクガクする，右手化力が入り難いな どの症状毛加わった，また，先の閒に一過性の複視を訴

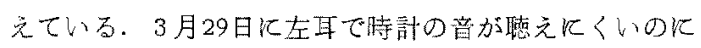
気付いたが，耳鳴は自筧しなかった。

1973年 4月19日: 九大耳界科受讋

1973年7月19日：いった九消失していた目觉症が再び 起り，更に食物の味が判りにくい，门腔内で食物の位置 が判りにくいなどの自敩症屯加わった。主た，手尼で風 昌晹の温度が判りにくいと訴えている。

1976年7月29日：自営症は全く無い，前回の診祭加 現在まての的 2 年半の間任, 前述の放状が数回起ってい るが、いつれも怪く経過したという。全経過者通じて, 舆览, 構音, 意識, 視力などの障害は全く認められず,

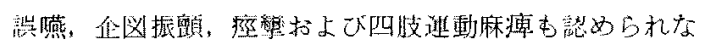
かった。

\section{検查成績の経過}

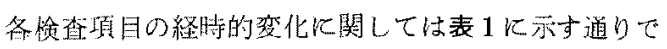
ある、純音㯖力ならびに TTSの経過はそれぞれ図 1 郘 よび図2にボした。

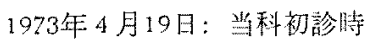

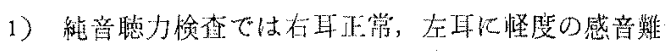

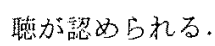

2) 自記オージオグラムでは，500 Hz 以上の周波数

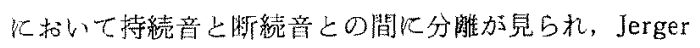
II 辈心 TTS祭性を柰した。

3) tone decay test (TDT 上視略)では 1000-8000 $\mathrm{Hz}$ で著明な眿性在示した。

4) 自発眼振については，在右注視方向性眼振扣上び

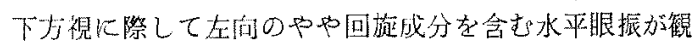
察され，Frenzel 眼鏡下の頭位眼振検省では左问の力向 固定性の水平腿振が㪊められた（図 3 ).

5) Hallpike 法によ名泠温交互温度眼振检查ては, 将明左向 DP 加観察された（図 4).

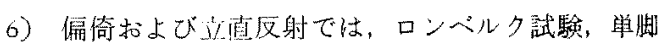

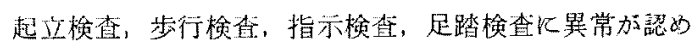
られたが，失調性觜子は全く涊められなかった。

第 1 垡

\begin{tabular}{|c|c|c|c|c|c|c|c|}
\hline & 1973.4 .19 & 1973.4 .27 & 1973.5 .2 & 1973.5 .28 & 1973.8 .25 & 1974.1 .14 & 1976.7 .29 \\
\hline 注 視 眼 提 & 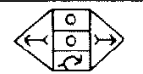 & स०० & $\left\langle\begin{array}{l}0 \\
0 \\
0\end{array}\right.$ & - &.- & - & - \\
\hline 到 位 眼 振 & $r \underset{\leftrightarrow \rightarrow}{\Leftrightarrow \rightarrow}$ & \begin{tabular}{|l|l|l|} 
& 0 & \\
0 & 0 & 0 \\
& 0 & \\
\end{tabular} & - & - & - & - & - \\
\hline 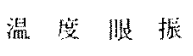 & $\mathrm{x}_{\mathrm{A}}$ & 怪论有 C P & - & & $\frac{1}{\mathrm{Cl}}$ & -- & - \\
\hline 产直，编伤 & H & \pm & - & - & - & - & - \\
\hline $\mathrm{OKN}$ & - & - & - & & - & - & - \\
\hline $\mathrm{ETT}$ & & - & - & & $\ldots-$ & - & - \\
\hline 純 音㽞 力 & 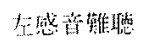 & 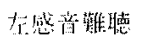 & 左感者嚾㯖 & 在感音踓槙 & 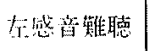 & - & - \\
\hline$R=$ & - & - & - & - & 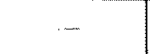 & - & - \\
\hline $\mathrm{TTS}$ & $t_{i}$ & $t_{1}$ & sit & 左 \pm & - & - & - \\
\hline T $\mathrm{D}^{\mathrm{T}}$ & 应 車 & t. & tr+ & ta & - & - & - \\
\hline 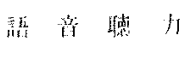 & & & - & & & & \\
\hline
\end{tabular}



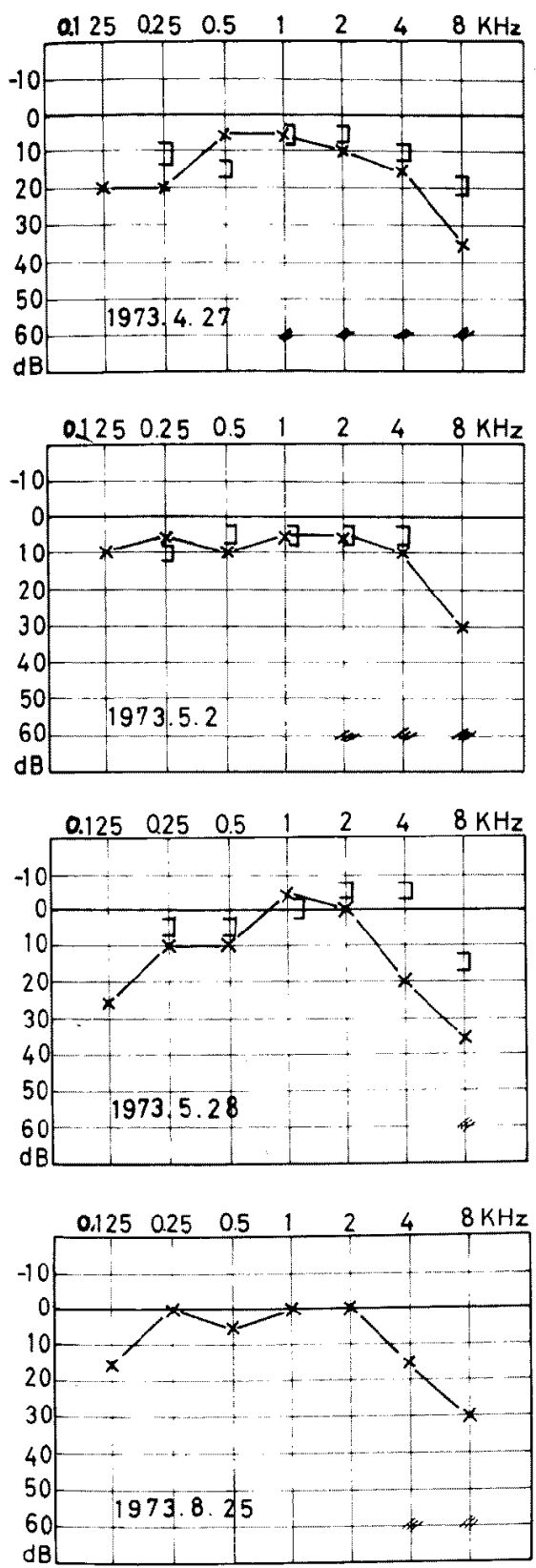

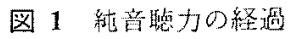
斜線はTDT晹性を正市

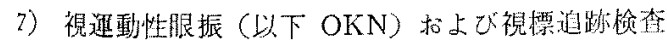

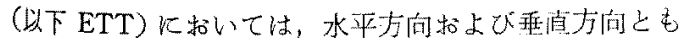
K異常は認められなかった。

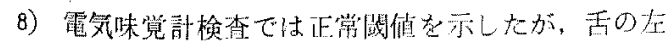

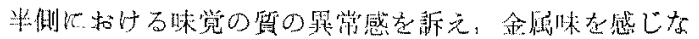
いし述心゙。

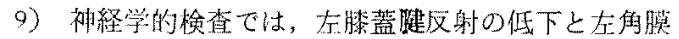

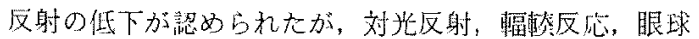
運動，舌咽・硕面の知筧・運動などに異常所見は晃られ なかった。

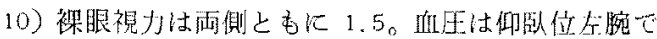
108-83。EEG は正常,

11) レントゲン検查でば, Schüller 法, Stenvers 法,

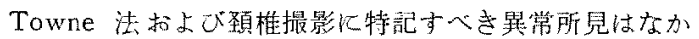
九.

1973年 4月27日:

1) 注視眼振は右方視の時だり构问水平眼振があり， 頭任眼振については左側位でのみ石问のやや回施性の水 眼振が琶められた。温度腿振梌查 (Hallpike 法)では 怪度の左 CP 走した。

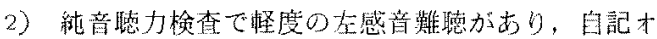

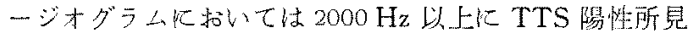

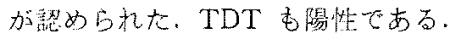

1973年5月2日: 自記才ージオグラムに振幅の增大が

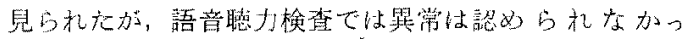
た。この4日捘に再检しているが，自記オージオグラん

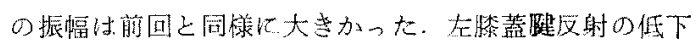
が榇めbれた。

1973年5月28日：純音渎力蚛よび目記才ージオグラム にな掉一部の周波数で買常所見が認められた。

1973年8月25日：純音㴔力乩よび TDT 亿一部の閣波 数で異常を認めるすのの，自記才ージオグラムはほぼ正 常となった。温度眼振㛟查 $\left(20^{\circ} \mathrm{C}, 5 \mathrm{ml}\right)$ で后倒の柽 度反応低下加諰められた。

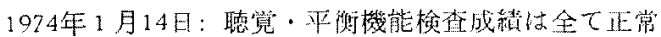

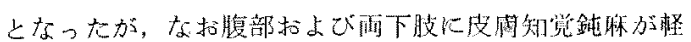
度ながら覕められた。

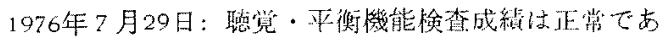

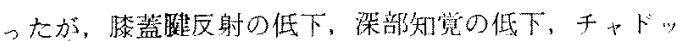

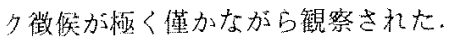

\section{考察}

1. 多発性砸化症について

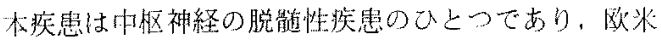

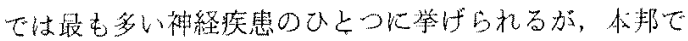
は韭常にまれとされている。米国では10万人に50人の制

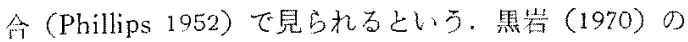

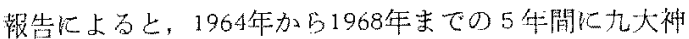




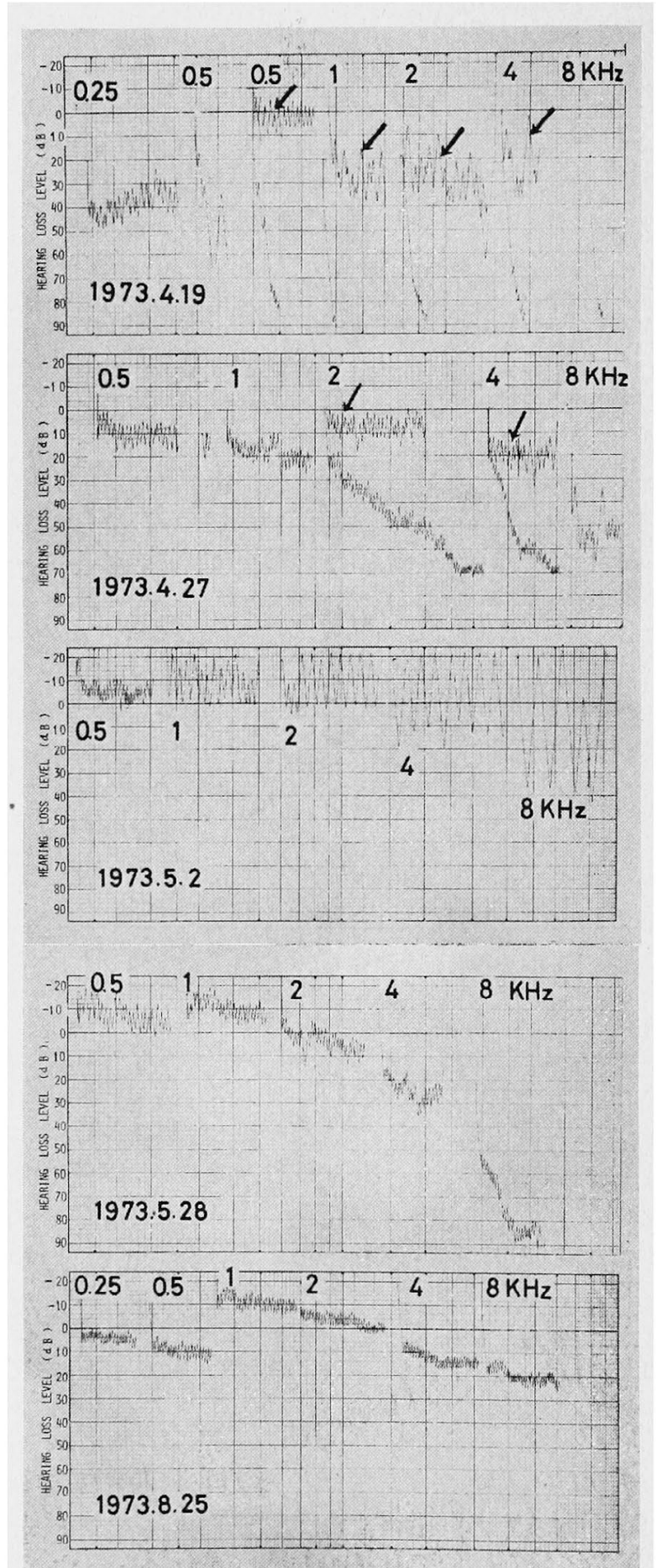

図 2 自記オージオグラム，TTS の経過

矢印のマークは断続音であり，その他の曲線は全て持続音による。 


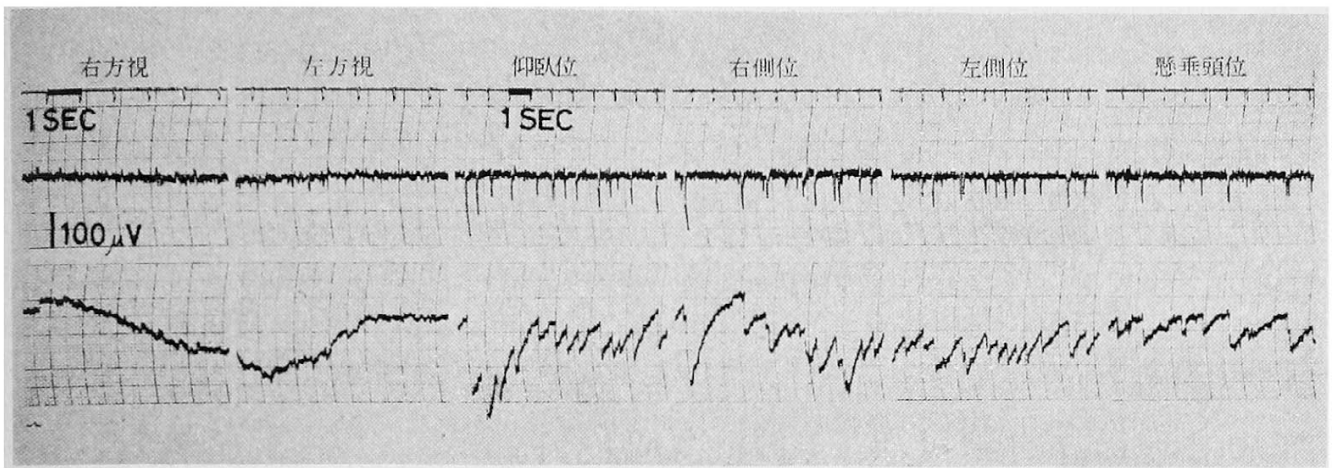

図 3 注視眼振特よび頭位眼振（初診時）

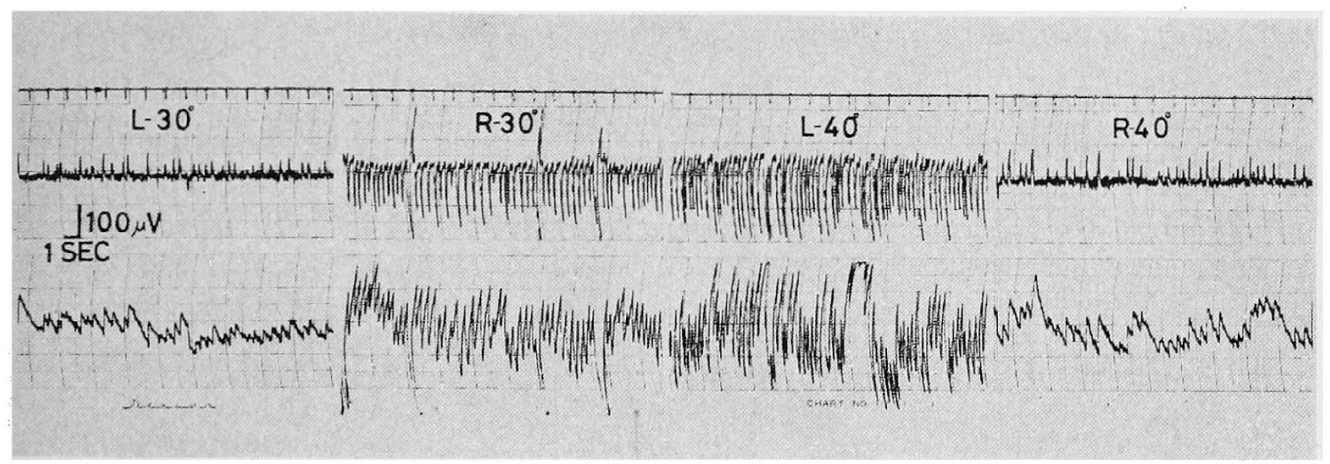

図 4 温 度 眼 振 (初診時)

経内科では, Schumacher の診断基準の全てまたはほと んど全てを満足した多発性硬化症と診断されたものは31 例である.

本疾患の臨床的特徴は病棵が多発性であり, 症状の緩 解が見られることである. 米国, 英国拈よびノルウェー で剖検によって確められた 111 例の本疾患をまとめた Poser 他 (1966) の報告では, その71\%に臨床的緩解が 認められていたという。また, Phillips (1952) は 50 例 中40\%が完全に症状の消失をみたと報告している. 病因 についてはウイルス感染説および自己免疫説が有力であ るが, 本疾患化対する決定的な specific diagnostic test は現在むなお無いとされている。発病初期には明確な他 党的所見の無いこともあって心因性疾患とまぎらわしい こともある.この点, 本症例でも, 結婚を間近に控えて の心因性疾患として対処されたこともあった．

神経耳科領域任直接関連のあるメマイ, 眼振, 耳鳴, 嚾㯖などの症状が突然発来することもあるといわれ，他 の神経学的異常所見にそしい時期にはメニエール病と誤
って診断されたこともうなづける. Carter (1950)の 46 例怙よび Poser (1966) の111 例の集計加ら見ると, 初 発症状としてのメマイは7\%执よび％と頻度は高くは ない。しかし，病变の経過中には眼振が85\%拈よび70\% に観察され，メマイは18\%扣よび15\%と出現頻度が増加 している．臨床診断によって本疾患とされた例から見る と, 耳鴆は 92 例中14例 (Leden 他 1948), 71 例中 17 例 (Aust 他 1973)，50例中 15 例（Keutner 1953）にそれ ぞれ認められている。

2. 本症例の障害部位について

鳃力障害は一側性であり, TTS 陽性, TDT 陽性, レ クリートメント陰性ということから, 蝸牛神経核, 聴神 経瀻維の障害による後迷路性難聴と考えられる。多発性 硬化症ではしばしば報告されているように，本症例に招 いても純音聴力損失は極く柽微にもかかわらず, TTSや TDTの著明な陽性所見が認められた，TTS 陽性所見が 正常化する途中で, 自記オージオグラムの曲線に大振幅 を記録したが，その時の語音聴力検査で異常は認められ 
ていないここの大振幅の望味については判然としない。

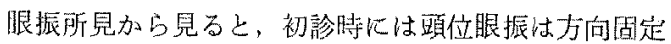
性であり，このことは前庭种経核より本梢側の前庭障害

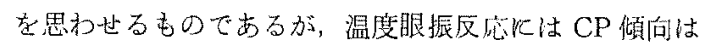
徍め得ず，また，注視眼振で注視方向性眼振を認めて いるので，一側卡梢性の前庭路障㫪だけでは説明しにく い。市小方，前庭第 2 次線維の病变も同㭙炕存在した

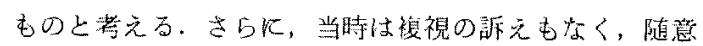

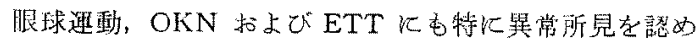
ていないので，本症例の自発眼振は眼運動系自体の障豈 によるものてはなく，前庭性起因のものであったと考え る。病状の経過とともに，温度眼振左 CP 扎よび右向自 発眼振入と推移して正常化して行った過琹加ら考祭する と，聴敩路病装に一致して左側の第 8 神経線維ないしは

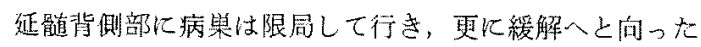
のであるら。

回転感至伴ったメマイは前庭路障害によると考えられ るが，経過中比しばば挀えられた步行障暃と平衡失調

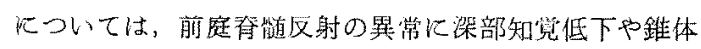
路拝状も加的って意起されたもの上瑟解される。初発症 状としての顔面知賞釛脎や一側盾膜反射低下は三叉种経

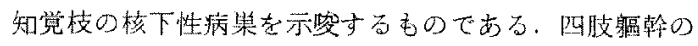
知覚障彗としては，C6-Th 1, Th 7-S 20頜域に特飞温

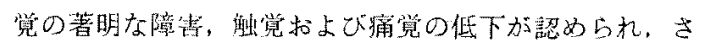
らに不宽全な加ら Brown-Sequard 症俣毛観察されて

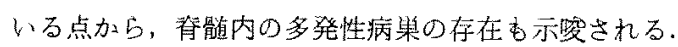

3. 㴔觉执よび前庭障整に関する文献的考察 聴筧について:

多発性硬化症の㯖觉路障害については，すで跂神経 楾維に病変のあることが(Schlesinger 1913)，また中枢

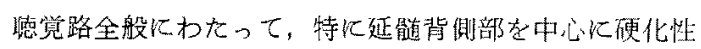

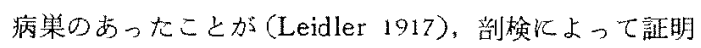

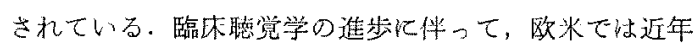
多くの臨床的㛟索がなれている. Simpkins (1961) は

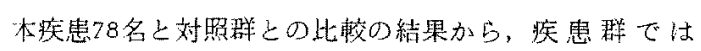

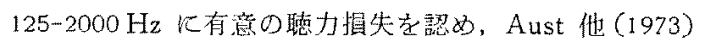

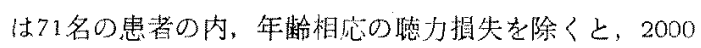
$\mathrm{Hz}$ 以上の高音域損失例が $24 \%$ \%見bれた上報告してい る. Parker（1968）によれば一般に㰌レヴェルの病宛で は純音䦚值は比較的上く保たれて怙り，患者の60\%は 20dBないしはそれよりも憙力は良加ったという. LeZak (1966)は本疾患に特有の鳆力像はなかったと報告してい

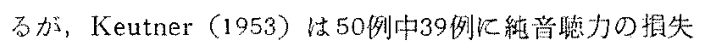

が罗られ，特に低高音部の損失が著明であったと述べて いる、Dayal 他 (1967) は隌音域損失型と水平型が最も

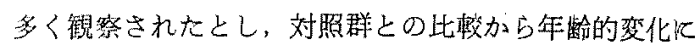
よること否定し，脱䯣の過程に生じた腹觉路の㜔害の 結果てあると結詥している. 更に Dayal 他 (1970) は 67\%の患者は斜昇型の㯖力損失を示し，次に17\%が水平

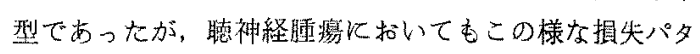
一ンを亦守例も多いので，共化第 8 神経を含む病变の結

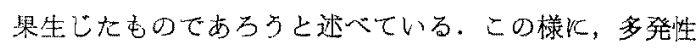
硬化症では特有の純視德力搷火のパターンは無いと言っ てよいであるう。

レクリートメント現象に関しては，本疾糨であっても

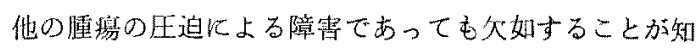
られている(Dix 1965). しかしながら, Parker (1968)

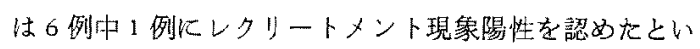
う.自記オージオグラムによるTTS では, 著明な陽性所 胃が見られることが Rose (1964)によって報告され，脱 髄自体によって㴔起されるだけでなく，近隣の浮腫によ る能䩪八の影繁によっても起ることが述べられている.

Miller 他 (1966) は純音聴力と語音悖力は正常であっ たにむかか⿰力口す，TTS晹性の1例を報告し，Parker (1962) 毛純音聴力は正常で TDT 陽性の1例があった と報告している．䰷力障害は視力障害の後に発来するこ とが多いという報告（Hallberg 1956）すあるが，㯰覚・ 平衡障渋に関する症状発現の順序については一定の傾向 は無いようでる. Helmut (1956)は架発難聴の病因の ひとつとして多発性硬化应を等げているが，その1例は メマイを伴わす，一側耳の耳鹏と 2000-8000 Hz の聴力 指失があり，2力月後にも㯖力は回復しなかったという。

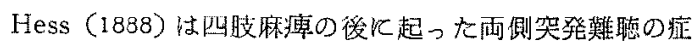
例安小し，原因を多発性硬化症化上るとしている。しか L一方, Leden 他 (1948) は本疾患92例o内, 㔖発的保 起った難㯖例然加つ大上報告している。

重第な聼力障害を来たした例飞ついては, Beck(1910) ば一侧耳隹完全器になった 3 例を，Engelhart (1.924)も

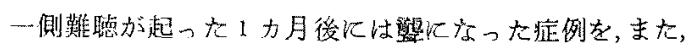

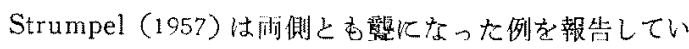
z.

鼠近, Lehnhardt $(1973,1975)$ は多発性硬化症の隐林

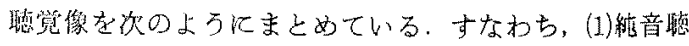
力は作常加または水平型のことが多い，(2) Békésy test やTDTで隄性所見を示可，持続音と断続音との閶に分

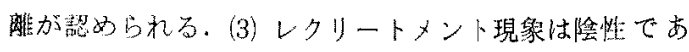




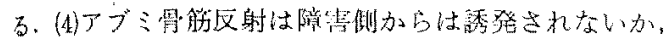

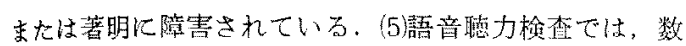
字の場合には純音婹打像加ら予測されるほど恶くはない が，単語音の場合にはその丁解度は著明に障㲘される。

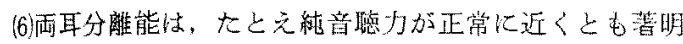
に障害されている. Colletti (1975) む13例についてう

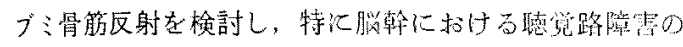
䧐断有用ですったと述べている。

前庭障害について:

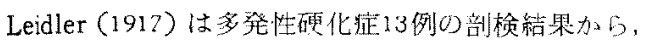

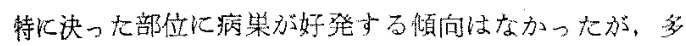

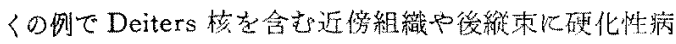

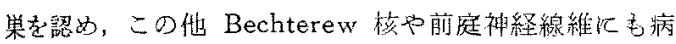
巣加認められたと記载している。. Leden 他 (1948)によ

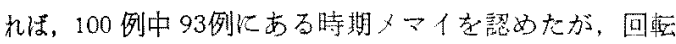

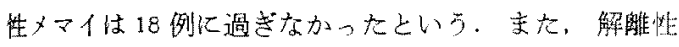
眼振などの特殊なタイプの眼振は観祭されていない。

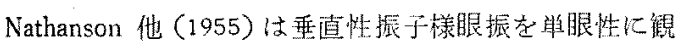

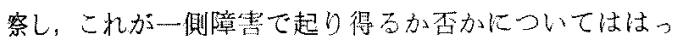
きりしないと述にている. Dayal 他 (1966)は17例の

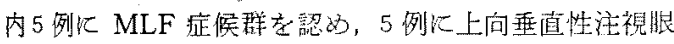

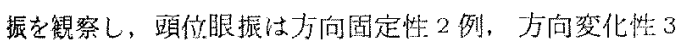
例であったという。さらに温度眼振反店はＣP 6例，DP

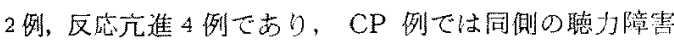
を伴う例が多がっという. Thomsen 他 (1973) も温涭 眼据反応の元谁を誈めている. Oettingen (1940)による と，60例のうち中枢性眼振示したの标23例で，内㷅惟

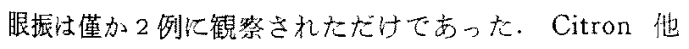
(1963)は急激に生した一唰難聴の柾例て，3週間後に姑 正常昫回復した興味ある例を報告している。すなわ方。 自発眼振は左向で, 埧度眼振と視跬動性眼振はともに在

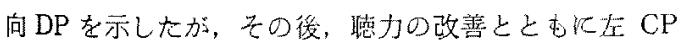
の回復毛認められている。これらの慗奏から左蛤牛种 経，左前庭神経和上び前庭小脳路に病身のあったこと省 推測している。

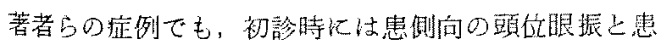
則向の温度眼振反心 DP があり，経過ととも《患例 CP

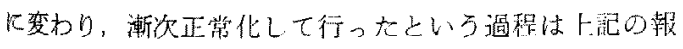
告借似している. Aust 他 (1973)は butterfly and L-chart 方式の温度眼振娭查加ら，71名中 $41 \%$ 例飞 中枢型の，4\%の例几本梢型（第1/イロン型）の暴常

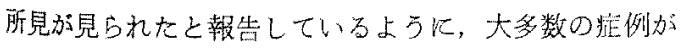
前庭神経核より中枢側の障圊であるから，多発性硬化症
に扰いては温度眼振反応の低下寺示す何が少いこともる なづける。

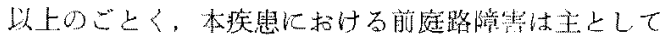

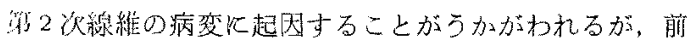
庭神経核中萠庭神経にも破化性病然の発生することも確 められているし，また，眼運動系自体に娄病焉在伴光

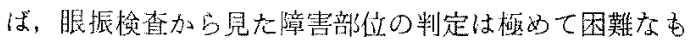
のたなであらう。本邦でも、MLF症候群など，種々の

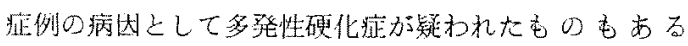
名，をれらにつ、ては螌れなか力大。

\section{¿ 9 ひ}

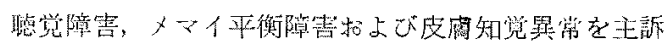

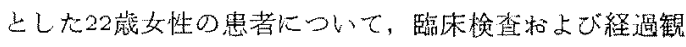
祭を行った結果加多発性硬化症亡猃断した。本疾患沉

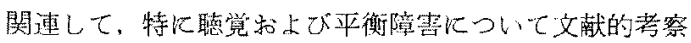
t加之た。

\section{文献}

1) Aust, G., E Clausen, C.F.: Über die Möglichkeiten der neurootologischen Diagnostik bei der multiplen Sklerose. HNO, 21; 46-48, 1973.

2) Beck, O.: Gehörorgan und multiple Sklerose. Mrschr. Ohrenheilk., 44; 1161-1172, 1910.

3) Carter, S., Sciarra, D. \& Merrit, H. H.: The course of multiple sclerosis as determined by autopsy proven cases. A. Res. nerv. \& Mient. Dis. Proc., 28; 471-511, 1950.

4) Citron, L., Dix, M.R., Hallpike, C.S., 8 Hood, J.D.: A recent clinicopathological study of cochlear nerve degeneration resulting from tumor pressure and disseminated sclerosis, with particular reference to the finding of normal threshold sensitivity for pure tones. Acta Otolaryng., 56; 330-337, 1963.

5) Colletti, $V_{.:}$Stapedius reflex abnormalities in multiple sclerosis. Audiology, 14; 63-71, 1975.

6) Dix, M.R.. Observations upon the nerve fibre deafness of multiple sclerosis, with particular reference to the phenomenon of loudness recuruitment. J. Laryng., 79; 695-706, 1965.

7) Dayal, V.S. \& Tarantino, L.: Neuro-otologic studies in multiple sclerosis. Laryngoscope, 76; 1798-1809, 1966. 
8) Dayal, V.S. \& Swisher, L. P.: Pure tone thresholds in multiple sclerosis. Laryngoscope, $77 ; 2169-2177,1967$.

9) Dayal, V.S., Kane, N. $\mathcal{E}^{2}$ Mendelsohn, M.: Pattern of pure tone hearing loss. Acta Otolaryngol, 69 ; $329-332,1970$.

10) Engelhardt, G.: Zur Symptomatologie der Oktavusausschaltung bei multipler Sklerose. $Z$. Hals-usw. Heilk., 8; 192-205, 1924.

11) Hess, K.: Ueber einen Fall von multipler Sklerose des Centralnervensystems. Arch. Psychiatr., 19; 64-87, 1888.

12) Harris, W.: Ataxic nystagmus: A pathognomonic sign in disseminated sclersis. Brit. Jour. Ophthal., $28 ; 40-42,1944$.

13) Helmut, G.: Hörstörungen bei multipler Sklerose. Excerpta Medica. Section II. Vol. 9; 292, 1956.

14) Hallberg, O.E.: Sudden deafness of obscure origin. Laryngoscope, 66; 1237-1267, 1956.

15) Keutner, $V . W$. Hörstörungen bei multipler Sklerose. HNO, 4; 133-135, 1953/1954.

16) Leidler, $R$.: Über die Beziehungen der multipler Sklerose zum zentralen Vestibularapparat. Mrschr. Ohrenheilk., 51; Z49-270, 1917.

17) Leden, H.V. \& Horton, B.T.: Auditory nerve in multiple sclerosis. Arch Otolaryng., 48; 51 $57,1948$.

18) LeZak, R.J. E Selhub, S.: On hearing in multiple sclerosis. Ann. Otolaryng., 75; $1102-$ $1110,1966$.

19) Lehnhardt, E.: Audiometrische Topodiagnostik im Hirnstamm. Z. Laryng. Rhinol., 52; 11-21, 1973.

20) Lehnhardt, E.: Hörstörungen bei multipler Sklerose. HNO, 23; 101-108, 1975.

21) Miller, J.W., Cody, D.T.R. \& Griffing, T.: Békésy audiometry: demonstration of interrupted tone temporary threshold shift. Laryngosope, $79 ; 2135-2139,1969$.

22) Nathanson, M., Bergman, P.S. \& Bender, M.B.: Monocular nystagmus. Amer. J. Ophthal,, 40; 685-692, 1955.

23) Oettingen, E. N.: Labyrinthäre Störungen bei multipuler Sklerose. Nervenarzt, 13; 264-268, 1940.

24) Phillips, J.W.: Otologic symptoms in multiple sclerosis. Laryngoscope, 62; 271-276, 1952.

25) Poser, C.M., Presthus, J. \& Hörsdal, O.: Clinical characteristics of autopsy-proved multiple sclerosis. A study of British, Norwegian, and American cases. Neurol. (Mineap.), 16; 791$798,1966$.

26) Parker, W., Decker, R. L. ऊ Gardner, W. H.: Auditory function and intracranial lesions. Arch. Otolaryng., 76; 425-435, 1962.

27) Parker, W., Decker, R. L. \& Richards, N. G.: Auditory function and lesions of the pons. Arch. Otolaryng., 87; 228-240, 1968.

28) Rose, R.M. \& Daly, J.F.: Reversible temporary threshold shift in multiple sclerosis. Laryngosope, $74 ; 424-432,1964$.

29) Schlesinger, H.: cited from Bárány, R.: Veränderung des spontanen Nystagmus bei Veränderung der Kopflage. Mrschr. Ohrenheilk., 47; 481-482, 1913.

30) Strumpel, P.: Doppelseitige Ertaubung als Initialsy mptom einer multiplen Sklerose. HNO, $7 ; 190,195 \% / 1958$.

31) Simpkins, W.T.: An audiometric profile in multiple sclerosis. Arch. Otolaryng., 73; 557$564,1961$.

32) Thomsen, J. \& Zilstorff, $K$. : Vestibular hyperactivity in the differential caloric test. ORL, 35; 258-265, 1973.

33）黑岩義五郎，柴嘴浩，井上尚英，松永宗堆，朴 忠腥：わが国の多篦性硬化症疾患群の疫学的特よび 統計的矿究。神維進少，14;607-614，1970。

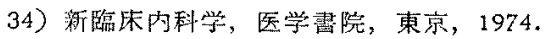

本諭文の望旨は第21回日本オージオロジー学会（1976 年12月）に拈いて砕告した。な㕲，本症例の㭘討に際し て数々のご助言をいたたいた九大神経病理・大田舆也助 教授に心から感謝しすす。

(原稿受付 昭和 51.12 .17 日)

原著者住所 T812 福岡市東区馬出 3-1-1 九州大学 医学部耳舅嗯喉科学教空 德永 修 